\title{
AFRICAN CHRISTIANITY AND THE ECOLOGICAL CRISIS - TRACING THE CONTOURS OF A CONUNDRUM
}

\author{
A.O. Balcomb \\ School of Religion, Philosophy and Classics \\ University of KwaZulu-Natal
}

\begin{abstract}
There has been a hot debate around Christianity's complicity in environmental destruction for some fifty years. The reasons are mainly to do with the so-called dominion mandate in the book of Genesis and the propensity for Christianity to "disenchant" the environment, that is rid it of spiritual agency. This has led to a comparison between Indigenous Religion and Christianity with respect to the environment with the former being the saint and the latter the sinner. Ecotheologies have emerged during this time in order to mitigate the negative influence of Christianity. These have in many cases attempted to emulate some aspects of Indigenous Religions. In the African context there are signs that the Christian mission continues to have negative effects on the environment and this raises the question of what would constitute an appropriate African Christian theology of the environment.
\end{abstract}

Key words: Environment; Eco-theology; Disenchantment; Indigenous Religion; Christianity

The debate around Christianity's complicity in environmental destruction has been raging for some fifty years. A concurrent and associated debate has been taking place around Indigenous Religions and the environment. The consensus appears to be that Christianity is the villain and Indigenous Religion the saint in the matter. In this essay I would like to summarize the arguments that have been put forward in this debate, discuss their relevance for contemporary explorations in eco-theology, and explore some of the possibilities for an African Christian theology of the environment.

\section{Christianity and the environment}

A watershed moment in the realization of Christianity's complicity in environmental destruction came with the publication of an article by the medieval historian Lynn White in 1967 entitled "The Historical Roots of our Ecological Crisis". ${ }^{1}$ Although White's thesis has been criticized this landmark publication paved the way for much of the present debate amongst scholars about the negative role of Christianity in the

Lynn White, "The Historical Roots of our Ecological Crisis", in This Sacred Earth-Religion, Nature, Environment, Gottlieb, R. (ed.), Routledge, New York, (1996), 184-193. This paper first appeared in Science, March 1967, 155, 1203-1207. 
environment. ${ }^{2}$ The domination of nature in Christianity, argued White, finds its roots in the Genesis creation narrative itself. The import of Gen. 1:26-28 is that dominion over creation is a characteristic of God and because humankind is made in the image of God humans too have dominion, with the creator, over the creation. In White's terms

Man shares, in great measure, God's transcendence of nature. Christianity, in absolute contrast to ancient paganism and Asia's religions ... not only established a dualism of man and nature but also insisted that it is God's will that man exploit nature for his proper ends. ${ }^{3}$

It is important to note first of all that White frames his critique of Christianity by way of a comparison with paganism, setting the tone for the debate that was to ensue. He stated his case in rather radical terms, arguing firstly that the "widespread practice of the Baconian creed that scientific knowledge means technological power over nature ..... mark[s] the greatest event in human history since the invention of agriculture, and perhaps in nonhuman terrestrial history as well", ${ }_{4}^{4}$ and secondly that "the victory of Christianity over paganism was the greatest psychic revolution in the history of our culture". 5 The first fundamentally shifted the relationship between human beings and nature from mutuality to dominance and the second led to the "exorcism", or, in Weberian terms, "disenchantment", from the environment of all spiritual significance which, in turn, led to the removal of restraints from exploitation of nature. This was in accordance with the Christian doctrine of the natural world being given to humankind to use and exploit for its own purposes. ${ }^{6}$

Kinsley summarizes the tradition of antipathy between Christianity and nature under three headings - desacralization, domination, and degradation. ${ }^{7}$ Desacralization, disenchantment, or demystification takes place when nature is emptied of spirituality, domination occurs when humans get the idea (from the Bible) that this is the command of God, and degradation follows through over-exploitation. Kinsley picks up the point strongly made by White that in the popular religion of antiquity "every stream, every tree, every mountain contained a guardian spirit who had to be carefully propitiated before one put a mill in a stream, or cut the tree, or mined the mountain". 8 On the other hand

For a critique of White see, for example, Hitzhusen G.E. "Judeo-Christian theology and the environment: moving beyond skepticism to new sources for environmental education in the United States", Environmental Education Research, vol 13, No 1, (Feb 2007) 55-74.

3 White in Kinsley D. Ecology and Religion-ecological spirituality in cross-cultural perspective, (PrenticeHall, New Jersey, 1995) 105.

4 White, "The Historical Roots of our Ecological Crisis", 185.

White, "The Historical Roots of our Ecological Crisis", 188.

6 In some ways it could be said that the entire system of private property in the West finds its inspiration in the Genesis narrative. This because John Locke, whose philosophy laid the foundation for the private ownership of land, justified his position from Genesis 1:28, following in the footsteps of Francis Bacon who was the first to articulate the need for an aggressive exploitation of nature.

$7 \quad$ Kinsley D. Ecology and Religion, 1995, 103.

8 White in Kinsley D. Ecology and Religion, 103. 
To a Christian a tree can be no more than a physical fact. The whole concept of the sacred grove is alien to Christianity and to the ethos of the West. For nearly two millennia Christian missionaries have been chopping down sacred groves which are idolatrous because they assume spirit in nature. ${ }^{9}$

Such an attitude finds its roots in the Hebrew Bible with the attitude of Israel to the Baal cult which was the indigenous religion of Canaan. This cult was based on "rapport with, reverence for, and propitiation of the powers latent in the land" ${ }^{10}$ Spirituality had nothing to do with the presence of the divine in the environment but with the transcendence of God over and above the environment. The environment is only sacred in that it is the creation of God and therefore indirectly bears the mark of God. The move from the indigenous belief that the environment itself is personal and has spiritual agency, to monotheistic religion where spiritual agency lies only with the transcendent deity constitutes, for White, the central radical shift that revolutionized the attitude of humankind to the environment and opened the way for exploitation and abuse.

White's thesis that this kind of exploitation of the environment finds its origins in the Hebrew scriptures under the dominion motif is confirmed by other scholars. John Austin Baker, for example, argues that the notion of the sovereignty of Jahweh in the Old Testament has led to the progressive depersonalization and demythologization of nature which led to the loss of the "numinous dread" of nature, and, under the one all powerful and transcendent God, places humankind in effective control of nature. ${ }^{11}$

This brings us to the relationship that Indigenous religions cultivate towards the environment.

\section{Indigenous Religion and the environment}

Firstly, it needs to be stated that the term "indigenous religion" is something of a misnomer because indigenous peoples do not recognize a religious sphere that is separate from life as a whole. The term indigenous "lifeway" is preferred by some authors as this emphasizes the "seamless cosmology-cum-economy character of indigenous societies". ${ }^{12}$ In spite of this the term "indigenous religion" continues to be used in the literature ${ }^{13}$ and I will use it here.

Secondly, contestation around the concept of the indigenous takes place mainly between essentialist as opposed to dynamic understandings of what knowledge is. The former assumes a body of knowledge that is defined in a particular way and has a particular ontological status and the latter emphasizes the process whereby knowledge is socially constructed through encounter and interaction with other forms of knowledge, making it essentially syncretistic. This essay will not go into this debate. Suffice to say that both of these understandings of indigenous knowledge are relevant. There are different forms of knowledge that can be defined in an ontological sense but this does

\footnotetext{
White in Kinsley D. Ecology and Religion, 104.

Kinsley D. Ecology and Religion, 106.

11 Baker J. "Biblical views of Nature", in Liberating Life - Contemporary Approaches to Ecological Theology, Brich C. Eakin W. and McDaniel J. (eds) (Orbis Books, Maryknoll, New York) 1990, 9-26.

12 John Grim, in the Introduction to Indigenous Traditions and Ecology - the inter-being of cosmology and community (Harvard University Press, Cambridge Massachusetts) 2001, xxxiv, John Grim (ed).

13 See for example Graham Harvey (ed) Indigenous Religions - A companion (Casell, London) 2001.
} 
not mean that they are not socially and historically constructed and constantly change through engagement with other forms of knowledge in particular contexts. The argument that knowledge is "essentially a social construction that results from a particular context and is being reshaped by the encounters and discontinuities that emerge at the points of intersection between actors' lifeworlds" 14 is particularly relevant for this discussion. John Grim appropriately locates this idea within the indigenous paradigm. "Contemporary indigenous lifeways and ecological cultures", he says, "are not 'pure' thought systems; rather they are distinct hybrids creatively influenced by the regional, national, and global regimes they have encountered and resisted". ${ }^{15}$

That Indigenous religion contributes towards environmental protection and not exploitation is supported by "voluminous ethnographic literature filled with carefully detailed examples of conservation practices, land stewardship, and religiously based environmental ethics among traditional peoples all over the world." 16 This does not mean that indigenous communities are faultless when it comes to environmental care. All human communities exploit nature to one extent or another. It is only a question of how much and with what effects. One of the theories that have emerged concerning Indigenous exploitation is what has been called "Pleistocene Overkill" in which Native Americans allegedly brought about widespread mammalian extinction. The theory seems to be highly contested and rubbished by some scholars. ${ }^{17}$ A counter argument maintains that the norms and regulations that establish responsible harvesting levels, discourage waste, and prevent ecological damage prevail among these communities is common to most of them. The reason for this, in Africa at least, is likely to do with taboos around the enchanted nature of the environment put forward in the White argument. Blasu, for example, argues that what he calls "eco-virtuous" character is a lifelong experience in primal (read "indigenous") African communities. ${ }^{18}$ This is based on the vulnerability to spiritual entities other than God in the precarious ecosystems, and is, according to him "the main reason why our ancestors establish both elaborate religious procedures (e.g. rituals) to manipulate the spirit forces and ethical rules (e.g. taboos) for prohibiting and inhibiting human conduct in the holistic eco-community". ${ }^{19}$

Romantic notions of harmony between humans and nature in indigenous worldviews largely miss this element. Care for the environment that grows out of an aesthetic or spiritual appreciation is one thing, care based on a mixture of fear, respect, and a sense of profound dependence on it is another altogether. The basic arguments that have been

14 Long N. and Villareal M. in Pottier, J. Negotiating Local Knowledge - Power and Identity in Development (Pluto Press, London 2003) 16.

15 Grim J. 2001:xxxix.

16 Richard Nelson in the prologue to Indigenous Traditions and Ecology - the Interbeing of Cosmology and Community, John Grim (ed), (Harvard University Press) 2001, 1xiii. For evidence that Indigenous cultures are being taken more seriously across the academic spectrum see Balcomb A. "Counter-modernism, the Primal Imagination and Development Theory - Shifting the paradigm", Journal of theology for Southern Africa, no. 157, (March 2017) 44-58.

17 For example Richard Nelson in the prologue to Grim's book, and also Raymond Pierotti, Indigenous Knowledge, Ecology, and Evolutionary Biology, (Routledge, New York, 2011).

18 Ebenezer Yaw Blasu, "Christian Higher Education as holistic mission and moral transformation: an assessment of studying environmental science at the Presbyterian University College, Ghana, and the development of an African Theological Curriculum", unpublished $\mathrm{PhD}$ thesis at the Akrofi-Christaller Institute of Theology, Mission, and Culture, pg108. 
put forward for such an attitude revolve around a number of interlinking beliefs and practices, for example that indigenous societies extend beyond the human to include beings that are other than human; that all these beings are profoundly interdependent; that the natural world is suffused with spirituality; that everything in the natural world is in some sense alive; and that responsible, sustainable, and non-exploitative use of the natural world is essential for the survival of both the human and other-than-human. ${ }^{20}$ Such a view of the environment has little or nothing to do with the romantic notions of nature held by some of the more famous lovers of nature such as Thoreau, Muir, and Leopold who argued that nature met the spiritual needs of humankind which modernity had robbed it of. ${ }^{21}$ Indigenous people, on the other hand, go much further than this as they "try to understand nature exactly as how it is so they can figure out how to survive and prosper within its changeable actions". ${ }^{22}$

Catherine Tucker's observation nicely summarizes the reason for the proenvironment position of Indigenous cultures.

Traditional peoples live within animate worlds of mutual obligations with spirits or nonhuman beings, and their beliefs constrain the behavior of members of the communities, ideally limiting their environmentally destructive behavior. Modernization processes, on the other hand, disenchant and despiritualize those worlds to enable life without the constraints and obligations. ${ }^{23}$

So from the Indigenous viewpoint there is nothing theoretical, philanthropic, or moral about being nice to the environment. It is more about pragmatism. If you do not take care of the environment it will punish you in some way. If you know what is good for you, you will recognize your obligations towards it. There is a kind Millsian utilitarianism at work here. You will be happy if everyone around you is happy. But in this case the "everyone" includes the entire living community, seen and unseen, human and other than human, earth, plants, peoples, and animals.

The major question that arises out of this background to the general understanding of the Christian and Indigenous Religions towards the environment is what has been happening in the encounter between these religions when it comes to environmental issues and what the significance of this is for the making of an African Christian ecotheology. The question is especially pertinent in the light of the fact that the Christian mission, as part of the modernizing project in Africa, is largely displacing, or at least

\footnotetext{
20 A classic example of sustainable use of resources from the natural environment among indigenous communities is the Bushmen. James Suzman's recent book on this subject strongly reinforces this perception. See Suzman J. Affluence without Abundance - the disappearing world of the Bushmen (Bloomsbury, New York, 2017).

21 See David Kinsley, Ecology and Religion, 1995 for a good summary of the Romanticist position on the environment.

22 Raymond Pierotti, Indigenous Knowledge, Ecology, and Evolutionary Biology (Taylor and Francis, New York, 2011) 16.

23 Catherine Tucker, Nature, science, and religion: intersections shaping society and the environment, (SAR Press, Santa Fe, 2012) 14.

23 For a fuller discussion of this see Anthony Balcomb, Journey into the African Sun - Soundings in Search of Another Way of Being in the World, (Unisa, Pretoria, 2014).
} 
profoundly transforming, Indigenous Religion in Africa south of the Sahara. ${ }^{24}$ This is not to say that Christianity itself is not being transformed or "enculturated" as it transacts with Indigenous Religion which, of course, has been well documented.

In what follows I will attempt to briefly summarise first of all how progressive theology in the West has responded to the basic challenges that White raised all those years ago with reference to the indigenous ("pagan") paradigm and then discuss the relevance of these for the making of an African Christian theology of the environment.

\section{The challenge - eco-theology in the wake of disenchantment}

More than four decades have passed since Lynn White threw down the gauntlet concerning the complicity of the Christian faith in environmental destruction. Over the ensuing period references to his article have continually appeared in the debates around theology and the environment and a wide range of theological responses have emerged. These have, in turn, been spurred on by the growing threat of climate change. The three main theological issues that White believed were at the heart of the problem were the transcendence of God, the dominion mandate of human kind over the earth, and the disenchantment of nature. At the heart of all of these issues is the nature of God, the relationship between God and human beings, and the relationship with the rest of creation. If God is creator and ruler of the universe and humankind is made in the image of God then humans are also rulers of the universe. If God transcends nature then nature is left devoid of God. So the basic tenets of theism have been questioned and the search for an embodied God who is present in the world and in creation has been emphasized through panentheism, which seeks to find the balance between imminence and transcendence. ${ }^{25}$ The concept of the imago Dei has been overhauled in the search for a deity who is less of a ruler and more of a servant. ${ }^{26}$ The essential relationality of God in the trinity and the extension of the concept of relationality to the whole of creation has been suggested as has the doctrine of the incarnation. Various forms of this can be seen in the attempts to re-enchant nature - to inject into nature the idea, if not the reality, of enchantment. This means re-inventing the notion that nature has agency or personality, thus the growing reference in the literature to non-human beings as being part of the community of human beings. ${ }^{27}$ Some have taken exception to the term "non" to be politically incorrect and rather called these citizens of nature "other than human beings". Ecofeminism and the Gaia hypothesis are obviously examples of these attempts to reenchant nature.

24 A comparison between a map of Africa in 1910 when the WCC held its first conference and 2010 one hundred years later showing the demographics of what was then called "animism" compared with Christianity sharply demonstrates the massive transformation that has taken place with respect to the displacement of Indigenous religions by Christianity in the sub region.

25 See for example Philip Clayton and Arthur Peacocke (eds) In Whom we live and Move and have our Being panentheist reflections on God's presence in a scientific world, (Eerdmans, Grand Rapids, 2004).

26 For a thoroughgoing overview and analysis of contemporary shifts in the theology of the Imago Dei see chapter three of Wentzel van Huyssteen Alone in the World - Human Uniqueness in Science and Theology, (Eerdmans Grand Rapids, 2006).

27 A fascinating example of this is Bruno Latour, Catholic French ethnographer with a penchant for trying his hand at theology, and argues that the concept of salvation needs to be extended to the non-human community. See Bruno Latour, "Will non-humans be saved? An argument in eco-theology", (Journal of the Royal Anthropological Institute, 15, 2009) 459-475. 
One cannot help noticing that all these attempts to reformulate Christian theology in a way that makes it friendlier to the environment boil down to trying to become more like Indigenous religions. The things within pagan religion that were condemned by the early pioneers of Christianity as idolatry and indeed, apparently by Jahweh himself in the Old Testament regarding Canaanite religion, are now seen to be important antidotes to environmental destruction! Many of the reforms, adjustments, overhauls, and visitations of past traditions in Christian theology amount to attempts to introduce into the Christian faith-world things that already exist in one form or another in the world of Indigenous Religion. Indigenous Religions never entertained the idea of the domination of humankind over the natural world, they never believed in a purely materialistic, "secular" existence without the presence of spirit, and their concept of a distant deity was mitigated by what Bolaji Idowu called "diffused monotheism" whereby the supreme deity influenced the world through a hierarchy of lesser divinities. ${ }^{28}$ Indeed in Indigenous Religions the attitudes, habits and dispositions necessary for environmental care are of the essence of these religions because they are constituents of the worldview in which they are embedded. Western Christian theology, on the other hand, has to contend with a secular worldview that has become so embedded within the western psyche that whatever changes may be made can only be a simulacra of the real thing. How does one re-enchant a disenchanted universe? How does one re-invite the deity to walk once more with us in the garden when, according to Christian tradition, not only has [s] he expelled us because of our disobedience (and allowed thistles and thorns to take over), but we, at least in the secular West, have now also expelled him/her?

In the search for an African theology of the environment the first thing that will need to be asked is whether the same kinds of things that White said happened wherever the Christian mission was established with respect to its effect on the environment are also happening in the wake of the Christian mission in Africa. The second question to be asked is whether the response of western theology as outlined above is appropriate in the African context. The answer to the first question is yes and to the second no, as I will now argue.

There is clear evidence, both anecdotal and empirical, to demonstrate that Christianity, in displacing indigenous religion in Africa, is contributing to environmental destruction in the way that has been described above. For convenience sake I will call the theory describing this process the disenchantment thesis.

In a recent research project funded by the Templeton Foundation in which I participated as principal researcher in 2017 two hundred and fifty (250) people from a cross section of the population ${ }^{29}$ in five African countries were interviewed on a wide range of topics, including the issue of the sacredness of the environment. The relevant question was: If you or someone else wanted to cut down a tree (e.g. on your property) that was considered sacred, what would you do? All of the respondents who were adherents of African Traditional Religion said they would not cut it down except one who said that it depended on whether or not the land itself was sacred. Only 16 out of 40

\footnotetext{
28 See Bolaji Idowu, Olodumare: God in Yoruba belief, (Longmans, London, 1962).

29 The countries where the research took place were Ghana, Ethiopia, Cameroon, Burkina-Faso, and Zimbabwe. The informants were distributed throughout the religious, denominational, educational, and age spectrums. Topics included marriage, customary tradition, relationships with spiritual beings, dreams, spirit possession, gender, success and failure in business, and corruption. A total of 7750 pieces of data were collected.
} 
Muslim respondents said they would cut down the tree. One of the Muslims maintained that Islam would not allow the tree to be cut down if it was sacred. Of the total responses, $37.2 \%$ said they would not cut the tree down, $57.6 \%$ of the respondents said that they would cut the tree down. Of this group of 144 people, 22 said that they would cut it down after prayer. Two people indicated that they would cut the tree down after consulting traditional leaders and seven said they would perform rituals first. They all considered that there would be spiritual consequences and so would take preventative action. Eight respondents said they would have been afraid to cut the tree down before they became Christians, but after conversion, they would cut it down without any fear of the consequences. The following response from one person was typical of many of the Christian respondents.

I will have it cut down. In fact, there were two such trees in the garden of my parents. A diviner (Bale Wuqabi) said that they were not to cut them lest bad things would happen to the family. I had it cut down after I came to Christ as a teenager. My mother and grandmother feared for my life, but nothing happened. These things are from the devil [Female 35-44, Married, University / Tertiary, Christian, Charismatic $]^{30}$

Although the clear majority of the respondents said they would cut down the tree the fact that twenty two of them said they would but only with prayer indicated that they considered the spiritual consequences of such an act. More significant is the fact that none of the ATR adherents would cut down the tree and eight said that they would cut it down because they were now Christians and did not believe in such things as sacred trees. ${ }^{31}$ Equally significant, however, is that a minority of Muslims said that they would cut the tree down. This is especially interesting in the light of the fact that one would think that Islam, possibly the most monotheistic of religions emphasizing the extreme sovereignty of the Creator, would be more inclined towards disenchantment.

While the evidence is clear from this particular piece of research that the disenchantment thesis is at play in the contemporary African scene there are also indications that there continues to exist a measure of mitigating restraint in the attitude of many of the respondents. A number of them did not believe they had carte blanche to do whatever they pleased with the environment. For example they would pray about cutting the tree down or they would consult others before they did so. The reason for such restraint and how it can be exploited in the articulation of an African ecological theology would be an important consideration when constructing such a theology.

Further evidence for the disenchantment thesis is to be found in the work of Allison Howell who has lived and worked in Ghana as a missionary, teacher and researcher for many years. In her 2017 Kwame Bediako Memorial Lecture she tells of how, when working among the Kasena in Northern Ghana, a Christian begged her to get him a chainsaw so he could cut down trees close to his home which were regarded as sacred, saying he no longer associated the trees with anything sacred and he did not consider it

\footnotetext{
30 Anthony Balcomb et al "Spirituality and Hope in Africa - a Study in Five Countries", International Bulletin of Missionary Research, Vol. 41, Issue 4, (October 2017) 336-347, 341.

31 Balcomb et al "Spirituality and Hope in Africa - a Study in Five Countries", 341.
} 
his responsibility to manage God's creation. ${ }^{32}$ She also cites the work of Christopher Affum-Nyarko who did his Masters degree in 2015 on Christian and Traditional Responses to Illegal Mining in Ghana. In the Western, Eastern and Ashanti Regions, in communities with a high concentration of galamsey (illegal mining) activity, he interviewed illegal miners, traditional leaders, church members and church leaders/pastors. Seven illegal miners who claimed to be Christians believed that 'God gave the earth and everything in it for our use. He will not prevent us from enjoying what He has created.' In their opinion, the traditional taboos should 'not hinder a human's quest to extract the natural resources of the earth for a living. ${ }^{33}$

Finally, another case study not on the African continent but in Papua New Guinea, documents an extreme form of disenchantment by evangelical Christians exercising "spiritual warfare" in Urapmin in the West Sepik province. Prior to the advent of the Christian mission in this region the people had a highly developed and complex cosmology where spiritual beings or "motobil" controlled the environment and the humans were seen as late comers and foreigners who were allowed to work the land but could not own it. A strict system of taboos regulated all activity in the natural environment. When Christian missionaries arrived mass conversions took place and a completely new spiritual regime was established in which the "motobil" were now seen as the usurpers and needed to be exorcized from the environment through prayer and intercession. This was done very specifically to clear the way for mining since rich reserves of copper and gold had been discovered there. The environment almost overnight became available for exploitation but any developmental intervention had to be accompanied by an initial bout of spiritual warfare against the motobil. A starker form of disenchantment of the environment in the interests of its exploitation can hardly be found. ${ }^{34}$

\section{What to consider in constructing an African Christian theology of the environment}

So far, the following important points have emerged in the discussion:

- Christianity was, and continues to be, complicit in environmental destruction and all that accompanies this, including climate change

- Indigenous Religion in many ways acts as exhibit A in how a religion can contribute to a healthy environment

- Christianity has become the dominant religion in sub-Saharan Africa and will continue to be massively influential in every aspect of life

- Conversion to Christianity from Indigenous Religion in Africa raises the spectre of a repeat of the theological failures of the past with respect to environmental issues

32 Allison Howell "African spirituality and Christian ministry: 'Discerning the signs of the times' in our environment and community" unpublished 9th Kwame Bediako Memorial Lecture delivered 7 June 2017 at the Akrofi-Christaller Institute, Akropong, Ghana.

33 Howell, "African Spirituality and Christian Mission", unpublished lecture, 8.

34 See J. Robbins "On Enchanting Science and Disenchanting Nature - Spiritual Warfare in North America and Papua New Guinea", in Nature, Science, and Religion, intersections shaping society and the environment, Mary Tucker (ed), School for Advanced Research Press, Santa Fe, (2012) 45-64. 
I have also made the argument that ecological theology in the West attempts to emulate some of the basic elements of Indigenous Religion. These are the numinous presence of the divine, the enchantment of nature, and the recognition that humans are vulnerable and interdependent beings amongst other beings who not human. Now if all of these are characteristic of Indigenous Religion, which continues to exist in various forms in Africa, then why can they not simply be appropriated into an African theology of the environment? Unfortunately it is not that easy. The Western theological project is largely taking place against the backdrop of secularism and the practical obliteration of the original indigenous religions. Emulating Indigenous Religion where it poses no threat whatsoever to one's essential (secular) beliefs is quite different from a situation where Indigenous beliefs are an ever present reality, where the lines are continually being drawn and where contestations continue to take place between it and Christianity. The world-view shared by these religions in an African context is fundamentally the same. God, the devil, and the supernatural, are existential realities and theology is to do with understanding and negotiating them in a way that concretely affects the way people live their lives. There is no place for the kind of "play" with different, interesting theological ideas that might be useful for particular purposes that characterizes theology in the West.

This became clear in the Templeton funded research mentioned above. When there is the widespread belief, for example, in the notion of spiritual marriage where people may enter, often against their will, into relationships with spiritual beings, the option of recognizing enchantment as a possible way to protect the environment becomes a little more consequential than in a context where such a notion is ludicrous. More specifically, to re-introduce as a theological necessity the notion of a spirituality of nature to someone who has recently been "saved" from a situation of "spiritual bondage" (that is the belief that they were subject to spiritual forces that were part of the panoply of principalities and powers against which they have been struggling) is clearly a risky proposition. ${ }^{35}$ Blasu's work, cited above, is illuminating in this regard.

Due to the holistic but precarious [nature] of African cosmology ... multifarious spirits vivify the cosmos, but malevolent ones may discourage belief in Christ and living the fulfilled Christian life. Hence salvation is understood as redemption from sin and evil forces, transformation into a new person and turning away from creation by waging war against the evil forces. ${ }^{36}$

If the taboos and rituals that lead to the protection of nature are motivated by fear of punishment from spiritual entities residing in nature and conversion amounts to freedom from such entities then further consort with them through some kind of "re-enchantment" regime in order to recreate a scenario where nature can be protected will surely not be an option. ${ }^{37}$

35 Birgit Meyer's work is significant in this regard. She demonstrates how suspicious the Ewe people were of attempts to contextualize the faith in cultural terms as this was perceived to compromise the faith and subject them to the very things from which they wanted to be "delivered". Birgit Meyer, Translating the devilReligion and Modernity amongst the Ewe in Ghana (Edinburgh, Edinburgh University Press, 1999).

36 Blasu, unpublished $\mathrm{PhD}$ thesis, 131.

37 Kalu asserts that there other more pragmatic reasons why Indigenous religion is not an option when he says that its ethics and practices are unable to withstand the onslaught of modernity on the environment. See Ogbu 
This, then, is the essence of the conundrum that is suggested in the title of this essay. While Indigenous Religion offers an example of best practice when it comes to the environment and many western theologians are falling over themselves attempting to emulate it, it does not remain an option for those who live close to it physically, spiritually, culturally, historically, and emotionally.

The question therefore remains - what considerations must be made when constructing an African ecological theology?

It is this question that I will now address very briefly.

\section{Some thoughts about elements of an African Christian theology of the environment}

Philip Jenkins is not far off the mark when he asserts that the dominant theological tone of emerging world Christianity is "traditionalist, orthodox, and supernatural". ${ }^{8}$ This is certainly the case with mainstream theology in Africa, that is, theology that does not include African Independent Churches. With this in mind an African theology of the environment will have three main characteristics - it will be theocentric, it will resonate with the motifs found in established theological traditions in the field, and it will be biblically based.

The centrality of God is a given in African theologies and eco-theology is no exception. The particular irony here is that in the Western ecological paradigm the attempt is to diffuse the deity as in panentheism and incarnation, as explained above. In Indigenous Religion in Africa the deity is already diffused, as in the notion of diffused monotheism. Conversion to Christianity personalizes the deity, incarnating it in Christ, and making it central to everyday existence. This means that an African eco-theology will need to work within a traditional, orthodox theism, albeit with a progressive, environmentally friendly slant.

Blasu explores a number of traditional, biblical themes for what he calls a "theocology" appropriate for the African context. Some of the themes that he unpacks are theocracy, viceregency, Sabbath rest, and kinship with the earth. I have found no better discussion of the topic and will therefore briefly summarize some of Blasu's ideas as well as add some others.

The strongly theocentric world view in Africa is summed up by Blasu in his assertion that "The eco-ethical [position] is that the All-Valuable and Good Creator is the only authoritative source and imputer of value and goodness to his creation, both human and non-human." 39 This theocentrism is reinforced by the belief that God not only created but rules the earth, that God's righteousness cannot be separated from ecological relationships in the ecosystem, that seeking God's kingdom is the motivation for right "ecological actions", and that we must put our faith in God as the creator and sustainer of the universe to provide the ultimate solution to our ecological crisis. ${ }^{40}$

Kalu "The Sacred Egg- Worldview, Ecology, and Development in West Africa", in Indigenous Traditions and Ecology - The Interbeing of Cosmology and Community, John Grim, 2001, 225-248. 
"A paradigm shift towards theocentrism", says Blasu, "will influence Environmental viceregency, which is our human responsibility to the environment and expression of faith that the whole cosmos is a living revelation of God." 41 The Viceregency of human beings finds its origins in the concept of Imago Dei and has traditionally emphasized the dominion motif. This is one of the doctrines that has been used to justify anthropocentric domination of the environment but a slew of theologians have reacted to this over the past three decades in the light of the ecological crisis and have come up with a range of revised interpretations of the doctrine. The following are some examples: Boff (both humans and non-humans have the same moral and sacramental value) $;{ }^{42}$ Victus (God is the prototypical ecologist and humans represent God in the ecosphere); ${ }^{43}$ Schwarz (Imago Dei does not signify a special ontological quality but is rather an assertion about the ecological function of humanity); ${ }^{44}$ Hefner (human beings become human through their relationships with the world and with God); ${ }^{45}$ Welker (humans are extremely close to the animal world and are "theologically designated to exemplify this and represent God's presence in the world"). ${ }^{46}$ Blasu uses the first two (among others) and the others, among many contemporary scholars across disciplines, are used by Van Huysteen in his post-foundational, interdisciplinary analysis of the notion of human uniqueness. ${ }^{47}$

The notion of Sabbath rest is interpreted ecologically - that is it is not so much to do with the rest of God or of humans but the rest of the natural environment which, through energy dissipation, needs to be refreshed. There needs therefore to be a shift away from the anthropocentric notion of human rest to the rest (read "non-exploitation") of environmental resources through taboos and regulations that ensure rejuvenation and regeneration. ${ }^{48}$ Blasu does not explain, however, where such taboos and regulations would come from in circumstances where people have moved on from an African Indigenous world-view.

Kinship with nature, says Blasu, should be part of a "reconstructed" Christian cosmology that takes into account some elements of African culture and worldview and combines them with a theology of the incarnation. When this is combined with the practice of birthing rites among some communities a powerful eco-theology is the result. As an example of this Blasu cites the birthing rituals of the Sokpoe-Ewe people of Ghana who bury the placenta and umbilical cord and place the new-born baby on the soil in order to "ground the baby as an earthling, which primes it for creation care as it grows into responsible status". 49

\footnotetext{
Blasu, unpublished PhD thesis, 129.

L. Boff Sacraments of Life-Life of sacraments, (Pastoral Press, Washington DC, 1996).

S. Victus Eco-Theology and the Scriptures: Revisit of Christian responses, (New Delhi, Christian World Imprints, 2014).

44 H. Schwarz Creation, (Eerdmans, Grand Rapids, 2002).

45 P. Hefner, The Human Factor: Evolution, Culture, and Religion, (Fortress, Minneapolis, 1993).

46 M. Welker, Creation and Reality, (Fortress Press Minneapolis 1999, Quoted from Van Huysteen, 2006$) 156$.

47 Van Huysteen, Alone in the World, 2006.

48 Blasu, unpublished PhD, 139.

49 Blasu, unpublished $\mathrm{PhD}$ thesis, 129.
} 


\section{Conclusion}

There is probably no set of issues of greater importance in the contemporary world than those that are to do with the earth on which we live and depend. The more alienated we become from it the more we contribute to our own destruction. In this essay I have picked up on the argument that certain beliefs that have been fundamental to Christianity have contributed to this alienation and destruction and attempted to demonstrate how they continue to play out in the Christian mission. While Indigenous Religions are clearly better placed to protect us from such destruction and their beliefs, ideas and practices should be heeded where they continue to exist, Christianity, as the dominant religion associated with the modern project, needs to be held to account and its theologies of the environment revisited, revised, and reconstructed with all urgency. I have argued that the allure of Indigenous Religion may remain for those historically and ideologically removed from the indigenous worldview and who have long since crossed the historical bridge to modernity but for those still struggling with the existential realities of a premodern world the luxury of indulging in such reflections hardly exists. What does exist, however, are opportunities to engage with the various traditions within Christian theology that deal with the topic of the natural world and to construct new ones in new and developing contexts. It is a most sobering revelation indeed that the fathers of the modern attitude to the exploitation and use of land (I speak of the likes of Locke and Bacon) drew their inspiration from scriptures such as Genesis 1:28. While their voice has been the dominant one in the West we are hopefully finally waking up to the destruction that has been caused and the need for alternative voices to be heard.

\section{BIBLIOGRAPHY}

Baker, JN 1990. "Biblical views of Nature", in Liberating Life - Contemporary Approaches to Ecological Theology, Brich C W. Eakin W. and McDaniel J., (eds) (Orbis Books, New York, Maryknoll,) 9-26.

Balcomb, AO et al. "Spirituality and Hope in Africa - a Study in Five Countries", (International Bulletin of Missionary Research, 2017, Vol. 41, 4) 336-347.

Blasu, E. "Christian Higher Education as Holistic Mission and Moral Transformation: an assessment of studying environmental science at the Presbyterian University College, Ghana and the Development of an African Theocology Curriculum", unpublished doctoral thesis completed in 2017.

Boff, L 1996. Sacraments of Life- Life of sacraments, Washington DC, Pastoral Press. Clayton, $\mathrm{P}$ and Peacocke, A (eds) 2004. In Whom we live and Move and have our Being - panentheist reflections on God's presence in a scientific world. Grand Rapids, Michigan, Eerdmans.

Grim, A (ed) 2001. Indigenous Traditions and Ecology - the inter-being of cosmology and community. Cambridge Massachusetts: Harvard University Press.

Harvey, G (ed) 2001. Indigenous Religions - A companion. London: Casell.

Hefner, P 1993. The Human Factor: Evolution, Culture, and Religion. Minneapolis: Fortress Press. 
Hitzhusen, G. "Judaeo-Christian theology and the environment: moving beyond skepticism to new sources for environmental education in the United States", Environmental Education Research, vol 13, No 1, (Feb 2007), 55-74.

Howell, A. "African spirituality and Christian ministry: 'Discerning the signs of the times' in our environment and community" unpublished 9th Kwame Bediako Memorial Lecture delivered 7 June 2017 at the Akrofi-Christaller Institute, Akropong, Ghana.

Idowu, I 1962. Olodumare: God in Yoruba belief. London: Longmans.

Jenkins, P 2011. The Next Christendom - the Coming of Global Christianity. New York: Oxford University Press.

Kinsley, D 1995. Ecology and Religion - ecological spirituality in cross-cultural perspective. New Jersey: Prentice-Hall.

Latour, B. "Will non-humans be saved? An argument in eco-theology", (Journal of the Royal Anthropological Institute, 15, 2009) 459-475.

Long, N and Villareal, M in Pottier, J (ed) 2003. "Negotiating Local Knowledge - An Introduction" in Negotiating Local Knowledge - Power and Identity in Development. London, Pluto Press, 1-29.

Meyer, B 1999. Translating the devil-Religion and Modernity amongst the Ewe in Ghana Edinburgh: Edinburgh University Press.

Pierotti, R 2011. Indigenous Knowledge, Ecology, and Evolutionary Biology. New York: Taylor and Francis.

Schwarz, H 2002. Creation. Cambridge: Eerdmans.

Suzman, J 2017. Affluence without Abundance - the disappearing world of the Bushmen. New York: Bloomsbury.

Tucker, C 2012. Nature, science, and religion: intersections shaping society and the environment. Santa Fe: SAR Press.

Van Huyssteen, W 2006. Alone in the World-Human Uniqueness in Science and Theology. Grand Rapids: Eerdmans.

Victus, S 2014. Eco-Theology and the Scriptures: Revisit of Christian responses. New Delhi: Christian World Imprints.

Welker, M 2006. Creation and Reality. Minneapolis: Fortress Press.

White, L. "The Historical Roots of our Ecological Crisis", in This Sacred EarthReligion, Nature, Environment, Gottlieb, R (ed.) (Routledge, New York, 1996), 184-193. This paper first appeared in Science, March 1967, 155(3767), 12031207. 